\title{
BERMAIN SEBAGAI METODE PEMBELAJARAN BAGI ANAK USIA DINI
}

\author{
Ahmad Zaini
}

Jurusan Tarbiyah STAIN Kudus

\begin{abstract}
Every parent can certainly always look forward to the baby's presence. The presence of children would add to the happiness in the household. For getting good education, children should start it at their early age even while still in the womb. Early childhood between 4 to 6 years known as pre-school age children are by the experts called them as the golden age, because the intellect in this period increased by 50\%. There are so many methods that can be done to children aged prematurely. One of them is playing. Learning while playing or playing while learning can be fun and entertaining for children. Playing will improve aspects of physical, mental, intellectual and spiritual children. They will find new things that have not ever known before. The playing has benefits and influences for children, including strengthening the physical (body) through muscular movements, develop personality, improve communication, and so on. The types of play that can be done is through the method of social playing, playing with objects and as well as playing a role. Each of these methods has its advantages and disadvantages of each. However, the important thing is not to impose less favorable learning them, because basically the world is a world-age children play, playing while learning or learning through playing method.
\end{abstract}

Keywords: early childhood, learning methods, playing

\section{A. Pendahuluan}

Kehadiran sang buah hati sangat dinanti-nantikan oleh setiap orang tua. Adanya anak-anak akan menambah kebahagiaan dalam rumah tangga. Anak-anak dilahirkan dalam keadaan fitrah seperti dijelaskan dalam sebuah hadis bahwa setiap anak dilahirkan dalam keadaan fitrah, orang tuanyalah yang menjadikannya sebagai Nasrani, Yahudi, ataupun Majusi. Artinya orang tua memiliki tanggung jawab yang besar dalam mendidik anak-anaknya agar tidak terjerumus ke jalan yang salah. Karena, al-Quran juga menyinggung 
bahwa anak dapat menjadi fitnah bagi para orang tua bila tidak dididik dengan sebaik-baiknya. Pendidikan akan memperoleh hasil yang baik bila dilakukan sejak usia dini.

Seperti diketahui bahwa anak adalah amanah yang harus dipertanggungjawabkan orang tua kepada Allah swt. Anak adalah tempat orang tua mencurahkan kasih sayangnya. Dan anak juga investasi masa depan untuk kepentingan orang tua di akhirat kelak. Oleh sebab itu orang tua harus memelihara, membesarkan, merawat, menyantuni dan mendidik anakanaknya dengan penuh tanggung jawab dan kasih sayang (Ilyas, 2000: 172). Rentang usia anak usia dini yaitu antara 4-6 tahun yang secara terminologi disebut juga sebagai anak usia pra sekolah. Usia demikian merupakan masa peka bagi anak. Para ahli menyebut sebagai masa golden age, dimana perkembangan kecerdasan pada masa ini mengalami peningkatan sampai $50 \%$. Pada masa ini terjadinya pematangan fungsi-fungsi fisik dan psikis yang siap merespon stimulasi yang diberikan oleh lingkungan. Masa ini merupakan tempo untuk meletakkan dasar pertama dalam mengembangkan kemampuan fisik, kognitif, bahasa, seni, sosial emosional, disiplin diri, nilainilai agama, konsep diri dan kemandirian (Isjoni, 2011: 19).

Karena pentingnya pendidikan anak usia dini, maka sangat dianjurkan kepada orang tua untuk memberikan vaksinasi dan selalu memberikan nutrisi lengkap dan seimbang kepada anaknya, agar anak mempunyai tubuh yang sehat, kuat dan otak yang cerdas. Orang tua juga harus memperlakukan anak secara hati-hati dan benar, agar anak memiliki karakter dan kepribadian yang tepat untuk perkembangannya lebih lanjut. Anak usia dini dapat digolongkan ke dalam anak usia pra-sekolah yang yang pertumbuhannya terbagi dalam dua tahap, yakni:

1. Usia sejak lahir s/d usia 2 tahun. Pada usia ini pertumbuhan anak lebih mengarah kepada fungsi-fungsi biologis. Ia menggunakan mulut sebagai sarana terpenting.

2. Usia antara 2-6 tahun. Pada usia ini perkembangan panca indra sangat menonjol, sehingga dalam proses belajarnya pun mereka menggunakan panca indra. Ada tiga macam perkembangan motorik (fungsi gerak), perkembangan bahasa dan berfikir, dan perkembagan sosial (Risaldy, 2014: 23).

Pendidikan bagi anak dimulai dari rumah, di lembaga PAUD atau Taman Kanak-Kanak juga lingkungan sekitar. Ketika mereka berada di Taman Kanak-Kanak maka mengajarkannya tidak bisa diperlakukan dengan kaku. Banyak metode pembelajaran yang dapat diterapkan bagi anak-anak 119 
usia dini, salah satunya melalui bermain. Belajar sambil bermain dapat menyenangkan dan menghibur bagi anak-anak. Bermain bagi anak adalah kegiatan yang serius tetapi menyenangkan. Menurut Montessori (2013: 77) pembelajaran yang sejati muncul dari kebebasan anak-anak untuk memilih kegiatan mereka dan untuk menyempurnakannya juga memerlukan perumusan kembali tentang apa makna dari seorang pengajar. Dalam kelaskelas konvensional, para pengajar, biasanya mengambil posisi di panggung pusat, sering kali berjuang untuk mendorong dan melibatkan sekelompok anak-anak yang memiliki tingkat kesiapan dan kemampuan yang berbedabeda. Karena itu pendidik ketika mengajari anak-anak didik yang masih usia dini harus dilakukan dengan cara yang menyenangkan.

Menurut Conny R. Semiawan seperti dikutip oleh Sabil Risaldy (2014: 29) bermain adalah aktivitas yang dipilih sendiri oleh anak karena menyenangkan, bukan karena hadiah atau pujian. Melalui bermain, semua aspek perkembangan anak dapat ditingkatkan. Dengan bermain secara bebas anak dapat bereksplorasi untuk memperkuat hal-hal yang sudah diketahui dan menemukan hal-hal baru. Melalui permainan, anak-anak juga dapat mengembangkan semua potensinya secara optimal, baik potensi fisik maupun mental intelektual dan spiritual. Oleh karena itu, bermain bagi anak usia dini merupakan jembatan bagi berkembangnya semua aspek.

Setiap anak memiliki bakat kreatif. Kreativitas merupakan salah satu potensi yang dimiliki anak yang perlu dikembangkan sejak dini. Ditinjau dari segi pendidikan, bakat kreatif dapat dikembangkan dan karena itu perlu dipupuk sejak dini. Bila bakat kreatif anak tidak dipupuk, maka bakat tersebut tidak akan berkembang, bahkan menjadi bakat yang terpendam dan tidak dapat diwujudkan. Melalui proses pembelajaran dengan kegiatan yang menyenangkan bagi anak-anak, yaitu melalui bermain, diharapkan dapat merangsang dan memupuk kreativitas anak sesuai dengan potensi yang dimilikinya untuk pengembangan diri sejak usia dini (Musbikin, 2010: 72).

Salah satu hasil riset menunjukkan, bahwa daya imajinasi, kreativitas, inovatif, dan proaktif lulusan PAUD berbeda dengan yang tidak melalui PAUD. Oleh sebab itu, PAUD terus ditumbuh kembangkan pemerintah. Ke depan sudah tidak bisa dtawar-tawar lagi lembaga ini harus dikembangkan sampai ke pelosok pedesaan. Dalam era global sekarang kita membutuhkan SDM yang berkualitas dan memiliki daya saing tinggi. Kita tidak inigin terusmenerus tertinggal dengan berbagai negara. Kita sepakat dapat sejajar dengan berbagai negara. Oleh sebab itu, sedini mungkin harus mempersiapkan SDM 120 yang handal, tentunya dimulai dari anak-anak usia dini sebagai upaya untuk 
menumbuhkankembangkan lembaga PAUD. Pemerintah sangat berperan dalam hal ini dan mestinya perhatian dari masyarakat juga sangat diharapkan (Isjoni, 2011: 39-40).

Dari paparan singkat di atas, maka artikel ini akan membahas tentang bermain sebagai metode pembelajaran bagi anak usia dini. Pembahasan dimulai dari pengertian pendidikan anak usia dini, urgensi pendidikan anak usia dini, prinsip-prinsip pendidikan anak usia dini, peranan keluarga terhadap pendidikan anak usia dini, pengaruh dan manfaat bermain, serta macam-macam metode bermain bagi anak-anak usia dini.

\section{B. Pengertian Pendidikan Anak Usia Dini}

Sebelum membahas lebih dalam apa yang dimaksud dengan pendidikan anak usia dini, maka kiranya perlu dijelaskan secara singkat perkembangan fase bayi dan kanak-kanak. Secara kronologis, masa bayi berlangsung sejak seorang individu manusia dilahirkan dari rahim ibunya sampai berusia sekitar setahun. Sedangkan masa kanak-kanak adalah masa perkembangan berikutnya, yakni dari usia setahun hingga usia sekitar lima atau enam tahun. Perkembangan biologis pada masa-masa ini berjalan pesat, tetapi secara sosiologis ia masih sangat terikat oleh lingkungan keluarganya. Oleh karena itu, fungsionalisasi lingkungan keluarga pada fase ini penting sekali untuk mempersiapkan anak terjun ke dalam lingkungan yang lebih luas terutama lingkungan sekolah (Syah, 2013: 49).

Pendidikan anak usia dini (PAUD) adalah suatu proses pembinaan tumbuh kembang anak sejak lahir sampai usia 6 tahun, yang dilakukan secara menyeluruh, mencakup semua aspek perkembangan dengan memberikan stimulasi terhadap perkembangan jasmani dan rohani agar anak dapat tumbuh dan berkembang optimal. Faktor yang mempengaruhi perkembangan anak ada dari orang tua (gen) dan ada faktor lingkungan seperti asupan gizi yang diterima, faktor psikologis, anak usia dini memiliki karakteristik yang khas, baik secara fisik, psikis, sosial, moral, masa ini masa yang paling penting untuk sepanjang usia hidupnya. Sebab masa yang paling baik pembentukan fondasi dan dasar kepribadian yang akan menentukan pengalaman anak selanjutnya. Bentuk program pendidikan anak usia dini meliputi: pendidikan keluarga, bina keluarga, taman pengasuhan, kelompok bermain dan taman kanak-kanak (Sudarna, 2014: 1).

Pada hakikatnya pendidikan anak usia dini adalah pendidikan yang diselenggarakan dengan tujuan untuk memfasilitasi pertumbuhan dan perkembangan anak secara menyeluruh atau menekankan pada 121 
pengembangan seluruh aspek kepribadian anak. Oleh karena itu, pendidikan anak usia dini memberi kesempatan kepada anak untuk mengembangkan kepribadian dan potensi secara maksimal. Kosekuensinya, lembaga pendidikan anak usia dini perlu menyediakan berbagai kegiatan yang dapat mengembangkan berbagai aspek perkembangan seperti: kognitif, bahasa, emosi, fisik, dan motorik (Suyadi \& Ulfah, 2013: 17).

Adapun secara insitusional, pendidikan anak usia dini juga dapat diartikan sebagai salah satu bentuk penyelenggaraan pendidikan yang menitikberatkan pada peletakan dasar ke arah pertumbuhan dan perkembangan, baik koordinasi motorik (halus dan kasar), kecerdasan emosi, kecerdasan jamak (multiple intelligences) maupun kecerdasan spiritual. Sesuai dengan keunikan dan pertumbuhan anak usia dini, penyelenggaraan pendidikan bagi anak usia dini disesuaikan dengan tahaptahap perkembangan yang dilalui oleh anak usia dini itu sendiri (Suyadi \& Ulfah, 2013: 17). Karena itu, pendidikan anak usia dini sangat urgen dilakukan sebagai proses pembinaan dan perkembangan bagi mereka.

\section{Urgensi Pendidikan Anak Usia Dini}

Pendidikan anak usia ini penting dilakukan, karena banyak hasil riset dan penelitian yang membuktikannya. Hasil kajian membuktikan bahwa pendidikan yang diberikan sejak dini berpengaruh signifikan terhadap perkembangan otak, kesehatan, kehidupan sosial dan ekonomi, serta kesiapan bersekolah. Hasil penelitian ini setidaknya menyadarkan berbagai pihak bahwa pendidikan dasar yang hanya mewajibkan anak usia SD dan SLTP untuk bersekolah perlu dikaji kembali; agar dapat menyentuh hakikat dan makna pendidikan yang sesungguhnya. Dalam hal ini perlu dipertimbangkan untuk menjadikan pendidikan anak usia dini (TK/RA) sebagai pendidikan yang wajib diikuti oleh seluruh anak bangsa sebelum memasuki pendidikan dasar. Hal ini penting, mengingat hasil penelitian tentang perkembangan otak bahwa sampai usia 4 tahun tingkat kapabilitas kecerdasan anak telah mencapai $50 \%$, pada usia 8 tahun mencapai $80 \%$, dan sisanya sekitar $20 \%$ diperoleh setelah berusia 8 tahun. Dengan demikian, jika pendidikan baru dilakukan pada anak ketika mencapai usia 6 atau 7

tahun (Sekolah Dasar), stimulasi lingkungan terhadap fungsi otak yang sebagian besar telah berkembang, akan terlambat pengembangannya sehingga tidak dapat berfungsi dengan baik. Kondisi ini dapat menyebabkan anak-anak kurang cerdas, serta dapat mengurangi optimalisasi potensi otak 122 yang seharusnya dimiliki oleh setiap anak (Mulyasa, 2012: 46-47). 
Adapun pentingnya pelayanan pendidikan anak usia dini (PAUD) menurut Sabil Risaldy (2014: 41) adalah sebagai berikut:

1. PAUD sebagai titik sentral strategi pembangunan sumber daya manusia dan sangat fundamental.

2. PAUD memegang peranan penting dan menentukan bagi sejarah perkembangan anak selanjutnya, sebab merupakan fondasi dasar bagi kepribadian anak.

3. Anak yang mendapatkan pembinaan sejak dini akan dapat meningkatkan kesehatan dan kesejahteraan fisik maupun mental yang akan berdampak pada peningkatan prestasi belajar, etos kerja, produktivitas, pada akhirnya anak akan mampu lebih mandiri dan mengoptimalkan potensi yang dimilikinya.

4. Merupakan masa golden age (usia keemasan). Dari perkembangan otak manusia, maka tahap perkembangan otak pada anak usia dini menempati posisi yang paling vital yakni mencapai $80 \%$ perkembangan otak.

5. Cerminan diri untuk melihat keberhasilan anak dimasa mendatang. Anak yang mendapatkan layanan baik semenjak usia 0-6 tahun memiliki harapan lebih besar untuk meraih keberhasilan di masa mendatang. Sebaliknya anak yang tidak mendapatkan pelayanan pendidikan yang memadai membutuhkan perjuangan yang cukup berat untuk mengembangkan hidup selanjutnya.

\section{Prinsip-Prinsip Pendidikan Anak Usia Dini}

Terdapat prinsip-prinsip bagi pendidikan anak usia dini. Menurut Tina Bruce seperti dikutip oleh Suyadi \& Ulfah (2013: 28) prinsip-prinsip pendidikan tersebut dirangkum dalam sepuluh prinsip pendidikan anak usia dini berikut ini:

1. Masa anak-anak adalah sebagian dari kehidupannya secara keseluruhan. Masa ini bukan dipersiapkan untuk menghadapi kehidupan pada masa yang akan datang, melainkan sebatas optimalisasi potensi secara optimal.

2. Fisik, mental, dan kesehatan, sama pentingnya dengan berpikir maupun aspek psikis (spiritual) lainnya. Oleh karena itu, keseluruhan (holistis) aspek perkembangan anak merupakan pertimbangan yang sama pentingnya.

3. Pembelajaran pada usia dini melalui berbagai kegiatan saling berkait satu dengan yang lain sehingga pola stimulasi perkembangan anak tidak 
boleh sektoral dan persial, hanya satu aspek perkembangan saja.

4. Membangkitkan motivasi intrinsik (motivasi dari dalam diri) anak akan menghasilkan inisiatif sendiri (self directed activity) yang sangat bernilai daripada motivasi ekstrensik.

5. Program pendidikan pada anak usia dini perlu menenkankan pada pentingnya sikap disiplin karena tersebut dapat membentuk watak dan kepribadiannya.

6. Masa peka (usia 0-3) untuk mempelajari sesuatu pada tahap perkembangan tertentu, perlu diobservasi lebih detail.

7. Tolak ukur pembelajaran pendidikan anak usia dini hendaknya bertumpu pada kegiatan yang telah mampu dikerjakan anak bukan mengajarkan hal-hal baru kepada anak, meskipun tujuannya baik karena baik menurut guru dan orang tua belum tentu baik menurut anak.

8. Suatu kondisi terbaik atau kehidupan terjadi dalam diri anak (innerlife), khususnya pada kondisi yang menunjang.

9. Orang-orang sekitar (anak dan orang dewasa) dalam interaksi merupakan sentral penting karena mereka secara otomotis menjadi guru bagi anak.

10. Pada haikatnya, pendidikan anak usia dini merupakan interaksi antara anak, lingkungan, orang dewasa, dan pengetahuan.

Selanjutnya menurut Sabil Risaldy (2014: 86) dalam prinsip-prinsip pelaksanakan pendidikan anak usia dini (PAUD) terdapat prinsip-prinsip utama yang harus diperhatikan. Prinsip-prinsip tersebut adalah sebagai berikut:

1. Mengutamakan kebutuhan anak. Kegiatan pembelajaran pada anak harus senantiasa berorientasi kepada kebutuhan anak. Anak usia dini adalah anak yang sedang membutuhkan upaya-upaya pendidikan untuk mencapai optimalisasi semua aspek perkembangan, baik perkembangan fisik maupun psikis, yaitu intelektual, bahasa, motorik, dan sosioemosional.

2. Belajar melalui bermain atau seraya belajar. Bermain merupakan sarana belajar anak usia dini. Melalui permainan, anak diajak untuk bereksplorasi, menemukan, memanfaatkan, dan mengambil kesimpulan mengenai benda di sekitarnya.

3. Lingkungan yang kondusif dan menentang. Lingkungan harus diciptakan sedemikian rupa sehingga menarik dan menyenangkan, sekaligus menentang dengan memperhatikan keamanan serta kenyamanan yang dapat mendukung kegiatan belajar melalui bermain. 
4. Menggunakan pembelajaran terpadu dalam bermain. Pembelajaran anak usia dini harus menggunakan konsep pembelajaran terpadu yang dilakukan melalui tema. Tema yang harus dibangun harus menarik dan dapat membangkitkan minak anak, serta bersifat kontekstual. Hal ini dimaksudkan agar anak mampu mengenal berbagai konsep serta mudah dan jelas sehingga pembelajarn menjadi mudah dan bermakna bagi anak didik.

5. Mengembangkan berbagai kecakapan atau keterampilan hidup (life skills). Mengembangkan keterampilan hidup dapat dilakukan melalui berbagai proses pembiasaan. Hal ini dimaksudkan agar anak belajar untuk menolong diri sendiri, mandiri, dan bertanggungjawab, serta memiliki disiplin diri.

6. Menggunakan berbagai media atau permainan edukatif dan sumber belajar. Media dan sumber pembelajaran dapat berasal dari lingkungan alam sekitar atau bahan-bahan yang sengaja disiapkan oleh pendidik, guru, dan orang tua.

7. Dilaksanakan secara bertahap dan berulang-ulang pembelajaran bagi anak usia dini hendaknya dilakukan secara bertahap, dimulai dari konsep yang sederhana dan dekat dengan anak. Agar konsep dapat kuasai dengan baik, hendaknya guru menyajikan kegiatan-kegiatan yang dilakukan berulang kali.

\section{E. Peranan Keluarga terhadap Pendidikan Anak Usia Dini}

Rumah adalah madrasah atau sekolah pertama bagi anak. Hal ini berimplikasi bahwa orang tua merupakan guru pertama bagi anak. Termasuk dalam kategori guru pertama bagi anak ini adalah kakek, nenek dan orangorang yang lebih dewasa dalam rumah tersebut (Suyadi \& Ulfah, 2013: 149150). Keluarga merupakan lembaga sosialisasi yang pertama dan utama bagi seorang anak. Melalui keluarga anak belajar berbagai hal agar kelak dapat melakukan penyesuaian diri dengan budaya di lingkungan tempat tinggalnya. Orang tua memegang peran penting dalam proses sosialisasi yang dijalani seorang anak. Seperti diungkapkan oleh Arnett sebagaimana dikutip oleh Sri Lestari (2014: 121) proses sosialisasi merupakan proses seorang anak belajar tentang perilaku dan keyakinan tentang dunia tempat ia tinggal. Seiring dengan tumbuh kembangnya anak mulai mengenal dunia yang lebih luas selain keluarga, sehingga sumber sosialisasi bagi anak pun semakin beragam. Selain keluarga, anak mulai mengenal teman sebaya, media, sekolah, komunitas, sistem hukum, dan sistem keyakinan dalam 125 
budaya.

Menurut Abdullah Nashih Ulwan seperti dikutip oleh Abu Muhammad Iqbal (2015: 239) orang tua sangat berperan dalam mendidik anak-anaknya, sehingga mereka akan terdidik dalam keutamaan akhlak dan akhirnya tumbuh dalam kebaikan. Pendidikan anak pada dasarnya adalah tanggung jawab orang tua. Orang tua sebagai pendidik utama hendaknya dapat berperan seoptimal mungkin agar anak memiliki nilai-nilai keutamaan sebagai pedoman dalam berperilaku.

Agar proses pendidikan anak usia dini berjalan baik, maka perlu ada keselarasan yang sama antara orang tua dan lembaga PAUD, sehingga rumah menjadi sekolah awal sebelum masuk PAUD. Dalam hal ini, sekolah atau PAUD-lah yang harus lebih aktif mensosialisasikan program-program pendidikannya untuk menyalaraskan dengan kegiatan anak-anak di rumah. Hal ini dimaksudkan agar kegiatan di rumah tidak bertentangan dengan kegiatan di sekolah (PAUD). Salah satu bentuk sosialisasi yang dapat dilakukan adalah dengan cara mengadakan forum bulanan yang dihindari oleh masyarakat sekitar wali murid, dan guru-guru PAUD. Dengan penyelarasan persepsi antara kegiatan di rumah dan program PAUD tumbuhkerkembang anak akan berjalan efektif. Atas dasar ini, berhasil atau tidaknya PAUD dalam mencerdaskan anak didiknya, tergantung pada efektivitas rumah sebagai "sekolah" pertama dan utama bagi anak karena anak-anak lebih banyak menghabiskan waktu bermainnya di rumah daripada waktu belajarnya di sekolah (Suyadi \& Ulfah, 2013: 150).

\section{F. Faktor-Faktor yang Mempengaruhi Permainan Anak}

Menurut Sudarna (2014: 161-62) bermain dapat mempengaruhi perkembangan jiwa anak. Adapun faktor-faktor yang dapat mempengaruhi perkembangan permainan anak adalah sebagai berikut:

1. Kesehatan. Anak-anak yang sehat mempunyai banyak energi untuk bermain dibandingkan dengan anak-anak yang kurang sehat, sehingga anak-anak yang sehat menghabiskan banyak waktu bermain yang membutuhkan banyak energi.

2. Intelegensi. Anak-anak yang cerdas lebih aktif dibanding dengan anakanak yang kurang cerdas. Anak-anak yang cerdas lebih menyenangi permainan-permainan yang bersifat intelektual atau permainan yang banyak merangsang daya pikir mereka, misalnya permainan drama, menonton film, atau membaca bacaan-bacaan yang bersifat intelektual.

126 3. Jenis kelamin. Anak perempuan lebih sedikit melakukan permainan 
yang menghabiskan banyak energi, misalnya memanjat, berlari-lari, atau kegiatan fisik yang lain dibandingkan anak laki-laki. Perbedaan ini bukan berarti bahwa anak perempuan kurang sehat dibanding anak laki-laki, melainkan pandangan masyarakat bahwa anak perempuan sebaiknya menjadi anak yang lembut dan bertingkah laku yang halus.

4. Lingkungan. Anak yang dibesarkan di lingkungan yang kurang menyediakan peralatan, waktu, dan ruang bermain bagi anak, akan menimbulkan aktivitas bermain anak berkurang.

5. Status sosial ekonomi. Anak yang dibesarkan di lingkungan keluarga yang status sosial ekonominya tinggi, lebih banyak tersedia alatalat permainan yang lengkap dibandingkan dengan anak-anak yang dibesarkan di keluarga yang status ekonominya rendah.

\section{G. Macam-Macam Bermain dan Manfaatnya}

Menurut Hughes seorang ahli perkembangan anak seperti dikutip oleh Imam Musbikin (2010: 98) paling tidak ada lima unsur dalam suatu kegiatan yang disebut bermain. Pertama, tujuan bermain. Tujuan bermain adalah permainan itu sendiri dan si pelaku mendapat kepuasan karena melakukannya (tanpa target), bukan untuk misalnya mendapatkan uang. Kedua, dipilih secara bebas. Permainan dipilih sendiri, dilakukan atas kehendak sendiri, dan tidak ada yang menyuruh ataupun memaksa. Ketiga, menyenangkan dan dinikmati. Keempat, ada unsur khayalan dalam kegiatannya. Kelima, dilakukan secara aktif dan sadar.

Bermain bagi anak-anak sangat memberikan manfaat bagi mereka. Anak akan mengenal berbagai jenis permainan dan masing-masing permainan ini memiliki manfaat yang berbeda-beda, sehingga kejiwaan mereka akan semakin berkembang. Menurut Sudarna (2014: 163-164) ada dua macam permainan, yakni permainan aktif dan pasif.

Pertama, permainan aktif.

1. Bermain bebas dan spontan atau ekplorasi. Dalam permainan ini anak dapat melakukan segala hal yang diinginkannya, tidak ada aturan-aturan dalam permainan tersebut. Anak akan terus bermain dengan permainan tersebut selama permainan tersebut menimbulkan kesenangan dan anak akan berhenti apabila permainan tersebut sudah tidak menyenangkannya. Dalam permainan ini anak melakukan ekperimen atau menyelidiki, mencoba, dan mengenal hal-hal baru.

2. Drama. Dalam drama, anak memerankan suatu peranan, menirukan karakter yang dikagumi dalam kehidupan yang nyata, atau dalam media 
massa.

3. Bermain Musik. Bermain musik dapat mendorong anak untuk mengembangkan tingkah laku sosialnya, yaitu dengan bekerja sama dengan teman-teman sebayanya dalam memproduksi musik, bernyanyi, berdansa, atau memainkan alat musik.

4. Mengumpulkan atau mengoleksi sesuatu. Kegiatan ini sering menimbulkan rasa bangga, karena anak mempunyai koleksi lebih banyak daripada teman-temannya. Di samping itu, mengumpulkan bendabenda dapat mempengaruhi penyesuaian pribadi dan sosial anak. anak terdorong untuk bersikap jujur, bekerja sama, dan bersaing.

5. Permainan olah raga. Dalam permainan olah raga, anak banyak menggunakan energi fisiknya, sehingga sangat membantu perkembangan fisiknya. Di samping itu, kegiatan ini mendorong sosialisasi anak dengan belajar bergaul, bekerja sama, memainkan peran pemimpin, serta menilai diri dan kemampuannya secara realistik dan sportif.

Kedua, permainan pasif.

1. Membaca. Membaca merupakan kegiatan yang sehat. Membaca akan memperluas wawasan dan pengetahuan anak, sehingga anak pun akan berkembang kreativitas dan kecerdasannya.

2. Mendengarkan radio. Mendengarkan radio dapat mempengaruhi anak baik secara positif maupun negatif. Pengaruh positifnya adalah anak akan bertambah pengetahuannya, sedangkan pengaruh negatifnya yaitu apabila anak meniru hal-hal yang disiarkan di radio seperti kekerasan, kriminalitas, atau hal-hal negatif lainnya.

3. Menonton televisi. Pengaruh televisi sama seperti mendengarkan radio, baik pengaruh positif maupun negatifnya.

Sedang menurut Y. Wiryasumarta dalam Tim Redaksi Familia (2003, 51-52) manfaat bermain adalah sebagai berikut:

1. Memperkuat fisik (tubuh) lewat gerakan-gerakan otot. Anak umur 4-6 tahun kadang-kadang tidak mengenal lelah. Mereka selalu gembira. Kegembiraan itu diekspresikan dengan berlari-lari, melompat, menendang bola, mendorong kursi, bermain ular-ularan, kucingkucingan, dan sebagainya. Lewat berbagai permainan itu, otot-otot mereka tumbuh dan berkembang secara wajar.

2. Mengembangkan kepribadian, melalui sikap sportif, jujur, kerja sama dan moral. Lewat bermain anak semakin bersikap positif dan mampu berinisiatif. 
3. Meningkatkan komunikasi, semakin mendekatkan hubungan antara anak dengan teman-temannya, orang tua, dan gurunya.

4. Melatih bermasyarakat. Lewat bermain anak-anak berlatih menaati aturan dan tata tertib permainan, serta melakukan hak dan kewajibannya. Bila anak melanggar aturan, ia akan dikenai sanksi/ hukuman dari teman-temannya atau akan dijauhi oleh mereka. Setiap anak tidak mau dikucilkan atau kehilangan teman bermain. Maka, ia akan mengormati dan menerima keputusan orang lain, tidak marah, tidak egois, belajar menanggung risiko, dan sebagainya.

5. Mengenal lingkungan sedini mungkin. Anak-anak menggunakan alatalat sebagai sarana bermain. Berbagai macam benda dimanipulasi untuk memenuhi hasrat bermain mereka. Dengan demikian, banyak benda dapat dilihat, didengar, diraba, dicium, dikecap, dan dimanipulasikan. Semakin banyak benda yang mereka kenal, bertambah pesat pula perkembangan persepsi mereka.

6. Mencegah dan menyembuhkan tekanan batin. Banyak ahli ilmu jiwa yang menggunakan permainan sebagai metode terapi/pengobatan awal bagi anak yang mengalami tekanan batin. Dengan bermain, anak mendapat kesempatan yang luas untuk melampiaskan kekesalan, melupakan kekecewaan, dan mendapatkan kembali ketenangan dirinya dalam bermain, anak akan melakukan apa saja untuk membuang beban berat yang dirasakannya.

7. Merupakan sumber belajar. Lewat bermain anak bisa melatih keterampilannya, menambah pengetahuan tentang konsep-konsep dasar dan hal-hal yang ada di lingkungan anak, serta memperkembangkan daya cipta.

\section{H. Bermain sebagai Metode Pembelajaran Bagi Anak Usia Dini}

Pembelajaran pada anak usia dini dapat dilaksanakan dengan menggunakan beberapa metode. Mengutip penjelasan dari Direktorat PADU tahun 2001 dan Depdikbud tahun 1998, Sabil Risaldy (2014: 30-32) menjelaskan beberapa metode pembelajaran di antaranya adalah sebagai berikut:

1. Bercerita. Bercerita adalah menceritakan atau membacakan cerita yang mengandung nilai-nilai pendidikan. Melalui cerita daya imajinasi anak dapat ditingkatkan. Bercerita dapat disertai gambar maupun dalam bentuk lainnya seperti panggung boneka. Cerita sebaiknya diberikan secara menarik dan membuka kesempatan bagi anak untuk bertanya 129 
dan memberikan tanggapan setelah cerita selesai. Cerita tersebut akan lebih bermanfaat juka dilaksanakan sesuai dengan minat, kemampuan dan kebutuhan anak.

2. Bernyanyi. Bernyanyi adalah kegiatan dalam melagukan pesan-pesan yang mengandung unsur pendidikan. Dengan bernyanyi anak dapat terbawa kepada situasi emosional seperti sedih dan gembira. Bernyanyi juga dapat menumbuhkan rasa estetika.

3. Berdarmawisata. Darmawisata adalah kunjungan secara langsung ke obyek-objek yang sesuai dengan bahan kegiatan yang sedang dibahas di lingkungan kehidupan anak. Kegiatan tersebut dilakukan di luar ruangan terutama untuk melihat, mendengar, merasakan, mengalami langsung berbagai keadaan atau peristiwa dilingkungannya. Hal ini dapat diwujudkan antara lain melalui darmawisata ke pasar, sawah, pantai, kebun, dan lainnya.

4. Bermain Peran. Bermain peran adalah permainan yang dilakukan untuk memerankan tokoh-tokoh, benda-benda, dan peran-peran tertentu sekitar aanak. bermain peran merupakan kegiatan menirukan perbuatan orang lain di sekitarnya. Dengan bermain peran, kebiasaan dan kesukaan anak untuk meniru akan tersalurkan serta dapat mengembangkan daya khayal (imajinasi) dan penghayatan terhadap bahan kegiatan yang dilaksanakan.

5. Peragaan/Demonstrasi. Peragaan/demonstrasi adalah kegiatan dimana tenaga pendidik/tutor memberikan contoh terlebih dahulu, kemudian ditirukan anak-anak. Peragaan/demonstrasi ini sesuai untuk melatih keterampilan dan cara-cara yang memerlukan contoh yang benar.

6. Pemberian Tugas. Pemberian tugas merupakan metode yang memberikan kesempatan kepada anak untuk melaksanakan tugas berdasarkan petunjuk langsung yang telah dipersiapkan sehingga anak dapat mengalami secara nyata dan melaksanakan tugas secara tuntas. Tugas dapat diberikan secara berkelompok ataupun individual.

7. Latihan. Latihan adalah kegiatan melatih anak untuk menguasai khususnya kemampuan psikomotorik yang menuntut koordinasi antara otot-otot mata dan otak. Latihan diberikan sesuai dengan langkahlangkah secara berurutan.

Dari sini, maka di antara metode pembelajaran yang telah disebutkan adalah melalui bermain. Bermain adalah salah satu pendekatan dalam melaksanakan kegiatan pendidikan untuk anak usia dini. Dengan 130 menggunakan strategi, metode/bahan dan media yang menarik, permainan 
dapat diikuti anak secara menyenangkan. Melalui bermain anak diajak untuk berekplorasi (penjajakan), menemukan, dan memanfaatkan berbeda-beda di sekitarnya (Suyadi \& Maulidya Ulfah, 2013: 34). Lanjut, Suyadi \& Maulidya Ulfah mengutip pendapatnya Montessori bahwa permainan sebagai "kebutuhan batiniah" setiap anak karena bermain mampu menyenangkan hati, meningkatkan keterampilan dan meningkatkan perkembangan anak. Konsep bermain inilah yang kemudian disebutnya sebagai belajar sambil bermain.

Sedang menurut Elizabeth Hurlock seperti dikutip oleh Suyadi (2010: 283) mendefinisikan bermain atau permainan sebagai aktivitasaktivitas untuk memperoleh kesenangan. Lebih lanjut dijelaskan bahwa bermain merupakan lawan dari kerja. Jika bermain dilakukan dengan penuh kesenangan dan kebahagiaan, bekerja belum tentu harus dilakukan dengan bahagia. Jika bermain bisa dilakukan tanpa beban, bekerja harus dilakukan dengan beban kewajiban tertentu. Jika bermain dilakukan tanpa tujuan atau hasil, bekerja selalu berorientasi pada hasil.

Bermain merupakan cara belajar yang sangat penting bagi anak usia dini tetapi sering kali guru dan orang tua memperlakukan mereka sesuai dengan keinginan orang dewasa, bahkan sering melarang anak untuk bermain. Akibatnya, pesan-pesan yang akan diajarkan orang tua sulit diterima anak karena banyak hal yang disukai oleh anak dilarang oleh orang tua, sebaliknya banyak hal yang disukai orang tua, tetapi tidak disukai anak. Untuk itu, orang tua dan guru pada lembaga pendidikan anak usia dini perlu memahami hakikat perkembangan anak dan hakikat pendidikan anak usia dini, agar dapat memberi pendidikan yang sesuai dengan jalan pikiran dan tingkat perkembangan mereka (Mulyasa, 2012: 167).

Papalia seorang ahli perkembangan manusia dalam bukunya Human Development seperti dikutip oleh Imam Musbikin (2010: 77) mengatakan bahwa anak berkembang dengan cara bermain. Dunia anak-anak adalah dunia bermain. Dengan bermain, anak-anak menggunakan otot tubuhnya, menstimulasi indra-indra tubuhnya, mengeksplorasi dunia sekitarnya, menemukan seperti apa lingkungan yang ia tinggali, dan menemukan seperti apa diri mereka sendiri. Dengan bermain, anak-anak menemukan dan mempelajari hal-hal atau keahlian baru dan belajar (learn) kapan harus menggunakan keahlian tersebut, serta memuaskan apa yang menjadi kebutuhannya (need). Lewat bermain, fisik anak akan terlatih serta kemampuan kognitif dan kemampuan interaksi dengan orang lain akan berkembang. 
Menurut Mulyasa (2012: 169-173) jenis-jenis bermain yang dapat digunakan sebagai metode pembelajaran bagi anak usia dini yaitu bermain sosial, bermain dengan benda, dan bermain peran.

\section{Bermain Sosial}

Dalam bermain sosial, gurulah yang mengamati cara bermain anak dan dia akan memperoleh kesan bahwa partisipasi anak dalam kegiatan bermain dengan teman-temannya akan menunjukkan derajat partisipasi yang berbeda. Parterm mengelompokkan kegiatan bermain berdasarkan derajat partsipasi seorang dalam bermain; yaitu unoccupied play (tidak peduli), solitary play (soliter), onlooker play ((penonton), parallel play (pararel), assosiative play (asosiatif) dan cooperative play (kooperatif).

\section{Bermain dengan Benda}

Bermain dengan benda merupakan kegiatan bermain ketika anak dalam menggunakan atau mempermainkan benda-benda tertentu dan benda-benda tersebut dapat menjadi hiburan yang menyenangkan bagi anak yang bermainnya. Oleh karena itu, lembaga-lembaga pendidikan anak usia dini harus menyiapkan berbagai permainan, sekaligus menyediakan benda-benda yang dapat digunakan secara aman dan nyaman bagi anak-anak dalam bermain. Tipe bermain dengan benda meliputi bermain praktis, bermain simbolik, dan bermain dengan aturan.

\section{Bermain Peran}

Pendidikan anak usia dini sering dihadapkan pada berbagai masalah, baik yang berkaitan dengan bidang pengembangan maupun menyangkut hubungan sosial. Melalui bermain peran, anak-anak mencoba mengekplorasi hubungan antar manusia dengan cara memperagakannya dan mendiskusikannya sehingga secara bersamasama dapat mengekplorasi perasaan, sikap, nilai, dan berbagai strategi pemecahan masalah. Sebagai suatu model pembelajaran, bermain peran berakar pada dimensi pribadi dan sosial. Dari dimensi pribadi model ini berusaha membantu anak-anak menemukan makna dari lingkungan sosial yang bermanfaat bagi dirinya. Dalam pada itu, melalui model ini anak-anak diajak untuk belajar memecahkan masalah pribadi yang sedang dihadapinya dengan bantuan kelompok sosial yang beranggotakan teman-teman sekelas.

\section{Penutup}

Dari paparan di atas dapat dijelaskan bahwa anak adalah amanah 132 yang harus dipertanggungjawabkan oleh para orang tua kepada Allah swt. 
Anak adalah tempat orang tua mencurahkan kasih sayangnya. Karena itu, para orang tua harus dapat memelihara, membesarkan, menyantuni dan mendidik anak-anaknya dengan sebaik-baiknya. Rumah adalah sebagai tempat pertama untuk mendidik bagi anak-anak. Adapun PAUD adalah sebagai tempat kedua bagi pendidikan dan pembelajaran bagi mereka. Setelah itu, barulah lingkungan sekitar sebagai tempat untuk mereka belajar bersosialisasi dengan masyarakat sekitar. Pendidikan anak usia ini penting dilakukan, karena banyak hasil riset dan penelitian yang membuktikan bahwa pendidikan yang diberikan sejak dini dapat berpengaruh secara signifikan terhadap perkembangan otak, kesehatan, kehidupan sosial dan ekonomi, serta kesiapan bersekolah.

Banyak metode pembelajaran yang dapat diterapkan bagi anak-anak usia dini, salah satunya melalui bermain. Belajar sambil bermain dapat menyenangkan dan menghibur bagi anak-anak. Bermain bagi anak adalah kegiatan yang serius tetapi menyenangkan. Bermain adalah salah satu pendekatan dalam melaksanakan kegiatan pendidikan untuk anak usia dini. Dengan menggunakan strategi, metode/bahan dan media yang menarik, permainan dapat diikuti anak secara menyenangkan. Seperti dipaparkan oleh Mulyasa di atas bahwa jenis-jenis bermain yang dapat digunakan sebagai metode pembelajaran bagi anak usia dini yaitu bermain sosial, dengan benda, dan bermain peran. Metode pembelajaran tersebut masingmasing memiliki kelebihan dan kekurangan. Tapi, yang terpenting adalah ketika bermain harus disesuaikan dengan minat dan bakat para anak-anak usia dini. Sehingga tujuan pendidikan bagi anak-anak usia dini dapat tercapai secara maksimal. 


\section{DAFTAR PUSTAKA}

Ilyas, Yunahar, Kuliah Akhlaq, Yogyakarta: Lembaga Pengkajian dan Pengamalan Islam (LPPI), 2000.

Iqbal, Abu Muhammad, Pemikiran Pendidikan Islam, Yogyakarta: Pustaka Pelajar, 2015.

Isjoni, Model Pembelajaran Anak Usia Dini, Bandung: Alfabeta, 2011.

Lestari, Sri, Psikologi Keluarga: Penanaman Nilai dan Penanganan Konflik dalam Keluarga, Jakarta: Prenada Media Group, 2014.

Maria Montessori, Metode Montessori: Panduan Wajib untuk Guru dan Orangtua Didik PAUD (Pendidikan Anak Usia Dini), diterjemahkan oleh Ahmad Lintang Lazuardi dari The Origin of an Educational Innovation: Including an Abridged and Annotated Edition of Maria Montessori's The Montessori Method, Yogyakarta: Pustaka Pelajar, 2013.

Musbikin, Imam, Buku Pintar PAUD (dalam Perspektif Islam), Yogyakarta: Laksana, 2010.

Mulyasa, Manajemen PAUD, Bandung: PT Remaja Rosdakarya, 2012.

Risaldy, Sabil, Manajemen Pengelolaan Sekolah Usia Dini, Jakarta: Luxima, 2004.

Sudarsana, Pendidikan Anak Usia Dini Berkarakter, Yogyakarta: Genius Publisher, 2014.

Suyadi \& Maulidya Ulfah, Konsep Dasar PAUD, Bandung: Remaja Rosdakarya, 2013.

Suyadi, Psikologi Belajar Pendidikan Anak Usia Dini, Yogyakarta: Pedagogia, 2010.

Syah, Muhibbin, Psikologi Pendidikan dengan Pendekatan Baru, Bandung: PT Remaja Rosdakarya, 2012.

Tim Redaksi Familia, Perilaku Anak Usia Dini, Yogyakarta: Kanisius, 2003. 